\title{
Evolution of Production Indicators over Time in Nelore Cows from the Bolivian Tropics
}

\author{
Atsuko Ikeda ${ }^{1} \&$ Pablo R. Marini ${ }^{1,2,3}$ \\ ${ }^{1}$ Facultad de Ciencias Veterinarias, Universidad Nacional de Rosario, Argentina \\ ${ }^{2}$ Centro Latinoamericano de Estudios de Problemáticas Lecheras (CLEPL), Argentina \\ ${ }^{3}$ Carrera del Investigador Científico (CIC-UNR), Argentina \\ Correspondence: Atsuko Ikeda, Facultad de Ciencias Veterinarias, Universidad Nacional de Rosario, Av. Ovidio \\ Lagos y Ruta 33, S2170HGJ, Casilda, Argentina. Tel: 591-7661-2126. E-mail: atsukoikedakato@ hotmail.com
}

Received: December 11, $2020 \quad$ Accepted: January 17, $2021 \quad$ Online Published: January 28, 2021

doi:10.5539/sar.v10n2p12 URL: https://doi.org/10.5539/sar.v10n2p12

\begin{abstract}
The objective of the present work was to analyze the evolution of the productive indicators over time in Nelore cows of the Bolivian tropics. The period between 1991 and 2016, corresponding to 3899 calvings of Nelore cows were used for the research work which belong to the Technology Center on Agriculture and Livestock in Bolivia belonging (FUNDATION CETABOL) and the Cooperativa Agropecuaria Integral San Juan de Yapacaní were used. Cows were ordered by birth period into three groups (1991-2000; 2001-2010; 2011-2016). The following variables were analyzed: Age at first calving in days, Live weight of cow in $\mathrm{kg}$, Calf weight at birth in $\mathrm{kg}$, Calf weight at weaning in $\mathrm{kg}$, Calving interval in days, Longevity in days, Accumulative Productivity in $\mathrm{kg}$ Total calf production (CP) in $\mathrm{kg}$. The age at first calving has decreased compared to the decade of 1991-2000, however the last period (2011-2016) has increased one more month compared to the period (2001-2010) showing significant differences $(p \leq 0.05)$. The weights of the cows and the calving interval followed the same behavior in the sense of decreasing, showing that in the period 2011-2015, the cows had the lowest live weight and the lowest calving-calving interval. The calf weight at birth showed an increase in the last two periods with significant difference $(\mathrm{p} \leq 0.05)$ with the period 1991-2000. That the longest-lived cows were those from the 1991-2000 period, showing significant differences $(\mathrm{p} \leq 0.05)$. The cows of the period 2001-2010 presented the best value of the Accumulated Production ( $\mathrm{p} \leq 0.05$ ), although the highest production of $\mathrm{kg}$ of weaned calf was for the cows of the period 1991-2000. It was concluded of the evolution of the productive indicators over time in Nelore cows from the Bolivian tropics individually showed an improvement in their indicators, although the analysis of the more complex indicators did not show an improvement in the results.
\end{abstract}

Keywords: longevity, accumulative production, aggregated indicators, zootechnic efficiency, grazing system

\section{Introduction}

The herds linked to the production of beef cattle in Bolivia, particularly in the departments of Santa Cruz and Beni, are currently applying technologies that translate into the supply of high genetic quality reproducers. In this context, the use of breeds that show adaptation to the particular environmental conditions of the region becomes important. The Nelore breed is the most important among the cattle breeds destined for the production of meat in Bolivia. Proof of this is that $8 \%$ percent of the beef cattle population corresponds to pure animals of this breed and 75\% to mestizo Nelore animals (Peredo, Etenssono \& Molina-Gomez, 2012). The incorporation of Nelore breed cattle into the production systems of the Bolivian tropics constituted an extraordinary advance in obtaining heavier animals with high daily earnings at a lower cost, that is, more efficient. In addition to its potential in terms of animal growth, two other important characteristics that define the biological aptitude of a breed cannot be omitted, such as survival capacity and reproductive potential (Flores \& Ortiz, 2010).

In the case of livestock production systems, the concept of efficiency refers to the adequate use of resources, with technology and with existing products and inputs. From this concept, a production process is considered efficient if the maximum number of outputs is obtained with the lowest possible inputs (Coelli, Rao, O'Donnell, $\&$ Battese, 2005).

Livestock producers require up-to-date and constant information that allows them to monitor the activity and 
plan actions that contribute to improving the system in such a way that they impact the finished product or output from the system. This information, presented in the form of indicators, should adequately reflect what happens in the production system and be used as a reference to know where each establishment is located at the time we analyze it (Marini \& Di Masso, 2018)

The indicators are intended to show in a simple and didactic way the achievements proposed in the production system, so that they can be easily understood and evaluated. The values associated with these indicators should mention to what extent the objectives set for the agricultural company are being met (Carstensen, 2013 \& Piccardi, 2014) as they help to understand where they are, where they are going and how far they are from the goals proposals (Marini \& Di Masso, 2018).

Since the late 1980s, the Fundation Centro Tecnológico Agropecuario has been working on a cattle herd in order to provide pure Nelore breeders for the genetic improvement of its associates' cattle herds. Basically the selection criterion was to obtain animals that achieved a daily gain that would allow us to wean a calf as heavy as possible.

The use of aggregated or integrated indicators in the beef-breeding systems for meat would allow evaluating the behavior of both the genotypes or racial groups involved, as well as the impact of the management strategies (non -genetic) on the biological and economic efficiency of the systems involved. Ikeda, Barbona, Hayashi, Pereira \& Marini (2019) raised the need to use indicators of this nature that help to avoid the overvaluation of a character to the detriment of all those involved, allowing to identify the biotypes most adapted to the different environments existing in the place of evaluation.

For this reason, the objective of this study was to analyze the evolution of the productive indicators over time in Nelore cows from the Bolivian tropics.

\section{Materials and Methods}

Retrospective data corresponding to the period between 1991 and 2016 were used for the research work which belong to the Technology Center on Agriculture and Livestock in Bolivia belonging (FUNDATION CETABOL) in Okinawa Japanese Community $\left(17^{\circ} 13^{\prime} 12^{\prime \prime}\right.$ south latitude, $62^{\circ} 53^{\prime} 39^{\prime \prime}$ west longitude) and the Cooperativa Agropecuaria Integral San Juan de Yapacaní (CAISY) located in Japanese Community San Juan $\left(16^{\circ} 59^{\prime} 0\right.$ " south latitude, $63^{\circ} 58^{\prime} 0$ " west longitude) Santa Cruz, Bolivia. The communities are located at 286 meters above sea level and they present a tropical climate, with significant rains in most months of the year and a short dry season with little effect on the general climate. The annual average temperature is $24.3^{\circ} \mathrm{C}$ with average rainfall of $986 \mathrm{~mm}$ in Japanese Community Okinawa and $1805 \mathrm{~mm}$ in Japanese Community San Juan in Santa Cruz.

\subsection{Animals}

The data corresponding to 3899 calvings of a primiparous and multiparous Nelore cows were used. Weaning occurs between seven and eight months in two or three stages depending on body and general condition. Gynecological control is performed routinely at weaning, by a technical advisor, as well as health.

\subsection{Feeding and Management}

The herd was fed grazing managed in intensive conditions, with cultivated pastures Brachiaria decumbens ( 8 to $12 \mathrm{t} /$ ha / year of DM), Brachiaria humidicola (8 to $10 \mathrm{t} / \mathrm{ha} /$ year of DM), Brachiaria dictyoneura (8 to $10 \mathrm{t} /$ ha / year of DM), Cynodon dactylon (10 to $20 \mathrm{t} / \mathrm{ha} /$ year of DM) and Panicum maximum cv mombaza (20 to 28 $\mathrm{t} /$ ha / year of DM).

\subsection{Variables to Analyze}

Age at first calving (AFC) in months (date of birth - date of first calving).

Cow live weight (LW) in $\mathrm{kg}$-The average cow weight of all the weights of her first lactation

Calf weight at birth (CWB) in kg- The average calf weight at birth for all calvings

Calf weight at weaning (CWW) in kg- The average calf weight at weaning of all calvings

Calving interval (CI) in days- The average calving interval of calvings.

Longevity (L) in days - Discard date or death - date of birth

Accumulative Productivity (PAC) in kg (Lôbo, Etenssono \& Molina-Gomez., 2000). 


$$
P A C=\frac{P_{d} * n_{p} * C_{a}}{E V P_{n}-C_{i}}
$$

PAC: $\mathrm{Pd}=$ average weight of weaned calves $(\mathrm{kg}) ; \mathrm{np}=$ total number of calves produced by the cow (calves born) $\mathrm{Ca}=$ constant equal to 365 days that allows to express fertility on an annual basis;

$\mathrm{EVPn}=$ age of the cow at the last calving (days).

The characteristics were analyzed using $\mathrm{Ci}=$ constant equal to 550 days approximately 18 months, representing the age at 1 st conception

Total calf production (CP) in $\mathrm{kg}$ - Total calf weight at weaning* Number of births

\subsection{Statistic Analysis}

Cows were ordered by birth period into three groups (1991-2000; 2001-2010; 2011-2016). The means and standard deviations were estimated and the Analysis of Variance and Tukey's comparison of means tests were applied ( $\mathrm{p}$ <.05). Statistical analyzes were performed with the JMP software package in its version 5.0 for Windows (JMP®, SAS Institute, 2003).

\section{Results}

Table 1 shows that the age at first calving has decreased compared to the decade of 1991-2000, however the last period (2011-2016) has increased one more month compared to the period (2001-2010) showing significant differences $(p \leq 0.05)$ between the three periods. The weights of the cows and the calving interval followed the same behavior in the sense of decreasing, showing that in the period 2011-2015, the cows had the lowest live weight and the lowest calving-calving interval. The calf weight at birth showed an increase in the last two periods with significant difference $(\mathrm{p} \leq 0.05)$ with the period 1991-2000, although the calf weights at weaning did not show significant differences $(\mathrm{p} \geq 0.05)$ between the three periods being Similar.

Table 1. Averages and standard errors of productive and reproductive variables according to period

\begin{tabular}{lllllll}
\hline Period & $\begin{array}{l}\text { Number of } \\
\text { calvings }\end{array}$ & $\begin{array}{l}\text { Age of first } \\
\text { calving (days) }\end{array}$ & $\begin{array}{l}\text { Live } \\
\text { weight }(\mathbf{k g})\end{array}$ & $\begin{array}{l}\text { Calf weight } \\
\text { at birth }(\mathbf{k g})\end{array}$ & $\begin{array}{l}\text { Calf weight } \\
\text { at weaning (kg) }\end{array}$ & $\begin{array}{l}\text { Calving } \\
\text { Interval (days) }\end{array}$ \\
\hline $1991-2000$ & 1566 & $1144 \pm 6^{\mathrm{a}}$ & $525 \pm 2^{\mathrm{a}}$ & $32.8 \pm 0.2^{\mathrm{c}}$ & $217 \pm 1$ & $449 \pm 3^{\mathrm{a}}$ \\
$2001-2010$ & 1787 & $1026 \pm 2^{\mathrm{c}}$ & $518 \pm 1^{\mathrm{b}}$ & $36.4 \pm 0.1^{\mathrm{a}}$ & $216 \pm 1$ & $431 \pm 3^{\mathrm{b}}$ \\
$2011-2016$ & 546 & $1058 \pm 6^{\mathrm{b}}$ & $497 \pm 2^{\mathrm{c}}$ & $35.7 \pm 0.2^{\mathrm{b}}$ & $218 \pm 2$ & $419 \pm 5^{\mathrm{b}}$ \\
\hline
\end{tabular}

Different letters in the column indicate significant differences $p \leq 0.05$

All values correspond to the arithmetic mean \pm standard error.

Cow live weight $(\mathrm{LW})$ in $\mathrm{kg}$ : average cow weight of all the weights of her first lactation.

Calf weight at birth (CWB) in kg: average calf weight at birth for all calvings.

Calf weight at weaning (CWW) in kg: average calf weight at weaning of all calvings.

Calving Interval (CI) in days.

Table 2 shows that the longest-lived cows were those from the 1991-2000 period, showing significant differences ( $\mathrm{p} \leq 0.05$ ), with a $40 \%$ reduction in longevity in the 2011-2016 period compared to the 1991-2000 decade. The cows of the period 2001-2010 presented the best value of the Accumulated Production ( $\mathrm{p} \leq 0.05)$, although the highest production of $\mathrm{kg}$ of weaned calf was for the cows of the period 1991-2000.

Table 2. Averages and standard errors of efficiency variables according to period

\begin{tabular}{lllll}
\hline Decade & Number of calvings & Longevity (days) & Accumulative Productivity (kg) & Calf production (kg) \\
\hline $1991-2000$ & 1566 & $2722 \pm 29^{\mathrm{a}}$ & $138 \pm 1^{\mathrm{b}}$ & $903 \pm 16^{\mathrm{a}}$ \\
$2001-2010$ & 1787 & $2353 \pm 24^{\mathrm{b}}$ & $144 \pm 1^{\mathrm{a}}$ & $779 \pm 13^{\mathrm{b}}$ \\
$2011-2016$ & 546 & $1735 \pm 21^{\mathrm{c}}$ & $134 \pm 2^{\mathrm{c}}$ & $473 \pm 14^{\mathrm{c}}$ \\
\hline
\end{tabular}

Different letters in the column indicate significant differences $p \leq 0.05$

All values correspond to the arithmetic mean \pm standard error.

Longevity (L) in days: Discard date or death - date of birth

Accumulative Productivity (PAC): Accumulated Productivity in kg of calf weaned per year.

Total calf production $(\mathrm{CP})$ in $\mathrm{kg}$ : Total calf weight at weaning * Number of births 


\section{Discussion}

The behavior of the indicators in table 1 could be explained by a deepening of the management (nutritional, forage planning and organization) that allowed them to arrive earlier at the first calving with a lower weight at their first calving and this had an impact on their adult live weight and improved the reproductive efficiency. The values found in the age at first calving were similar to those reported by Flores \& Ortiz (2010), the live weights of the cows to those reported by Segura-Correa, Magán-Morforte \& Centruion-Castro (2013), the calf weights at birth and at weaning above those shown by Santana et al. (2012); Boligon, Brignardi Mercadante Lobo \& Albunquerque. (2013); Chud et al. (2014); Ikeda et al. (2019).

If only the results of Table 1 are analyzed with disaggregated indicators. We could indicate that there was an improvement that the age at first calving, the adult live weight, the calving interval are decreased, calf weight at birth was increased and calf weight at weaning was maintained.

However, by including the results of table 2 with added indicators, it could be questioned whether there really was an improvement in the indicators of the cows analyzed over time. The work carried out to improve efficiency in livestock by the technology center has basically focused on improving the rate of weight gain determined during the growth phase (breeding-breeding). Although this approach would provide an adequate improvement on the efficiency of the rearing-rearing being one of the stages of the system, it would not be enough to show the productive efficiency of the system as a whole. In cows, the most critical factor influencing performance efficiency is lifetime reproductive rate and longevity, not live weight gain (Roberts, Funston, Mulliniks, Peterson \& MacNeol, 2011). Although, the consideration of each variable separately is relevant, since the values would allow evaluating the productive behavior over time, the characterization of the efficiency of the productive system requires the joint analysis of all of them rather than their individual consideration.

\section{Conclusions}

The analysis of the evolution of the productive indicators over time in Nelore cows from the Bolivian tropics individually showed an improvement in their indicators, although the analysis of the more complex indicators did not show an improvement in the results.

\section{References}

Boligon, A. A., Bignardi, A. B., Mercadante, M. E. Z., Lôbo, R. B., \& Albuquerque, L. G. (2013). Principal components and factor analytic models for birth to mature weights in Nellore cattle. Livest Sci, 152, 135-142. https://doi.org/10.1016/j.livsci.2013.01.005

Carstensen, K. A. (2013). A Comparison of the Efficiency and Profitability of Holsteins and Jerseys. Retrieved from https://goo.gl/p1Yt46

Chud, T. C. S., Caetano, S. L., Buzanskas, M. E., Grossi, D. A., Guidolin, D. G. F., \& Nascimento, G. B. (2014). Genetic analysis for gestation length, birth weight, weaning weight, and accumulated productivity in Nellore beef cattle. LivestSci, 170, 16-21. https://doi.org/10.1016/j.livsci.2014.09.024

Coelli, T. J., Rao, D. S. P., O’Donnell, C. J., \& Battese, G. E. (2005). An introduction to efficiency and productivity analysis. Springer Science \& Business Media. Retrieved from https://goo.gl/BvPK6n

Flores, V. H. D., \& Ortiz, T. T. J. (2010). Determination of the reproductive parameters of the Nelore bellies in the Parabano ranch (Cordillera Province, Santa Cruz Department). Tesis de grado FMVZ - UAGRM Santa Cruz - Bolivia, 57.

Ikeda, A., Barbona, I., Hayashi, Y., Pereira, J. A., \& Marini, P. R. (2019). Longevity of Nelore Cows of the Bolivian Tropics: Is It Possible to Explain It Through Productive Variables?. Sustainable Agriculture Research, 8(4), 28. https://doi.org/10.5539/sar.v8n4p28

Lôbo, R. N., Madalena, F. E., \& Vieira, A. R. (2000). Average estimates of genetics parameters for beef and dairy cattle in tropical regions. Animal Breeding Abstract, 68, 433-461.

Marini, P. R., \& Di Masso, R. J. (2018). Evaluación historica de indicadores productivos en vacas lecheras en sistemas a pastoreo. La granja: Revista de Ciencias de la Vida, 28(2), 103-115. https://doi.org/10.17163/lgr.n28.2018.08

Peredo, J. C., Etenssono, H. S., \& Molina-Gomez, S. W. (2012). Producción de ganado bovino en Bolivia. Federación de Ganadería de Santa Cruz, Santa Cruz, Bolivia. p. 3-20.

Piccardi, M. B. (2014). Indicadores de eficiencia productiva y reproductiva en rodeos lecheros PhD thesis Facultad de Ciencias Agropecuarias. Retrieved from https://goo.gl/V1vtCi. 
Roberts, A., Funston, R., Mulliniks, T., Petersen, M., \& MacNeil, M. (2011). Feed efficiency - how should it be used for the cow? Range Beef Cow Symposium. Retrieved from http://digitalcommons.unl.edu/rangebeefcowsymp/281

Santana, M. L., Eler, J. P., Cardoso, F. F., Albuquerque, L. G., Bignardi, A. B., \& Ferraz, J. B. S. (2012). Genotype by environment interaction for birth and weaning weights of composite beef cattle in different regions of Brazil. Livest Sci, 149, 242-249. https://doi.org/10.1016/j.livsci.2012.07.017

Segura-Correa, J. C., Magañ Monforte, J. G., \& Centurión-Castro, F. (2013). Effect of racial group and age at first calving on the number of calving during the lifespan of zebu cows. Universidad Autónoma de Yucatán, Merida, Yucatán, México. p. 41-44.

\section{Copyrights}

Copyright for this article is retained by the author(s), with first publication rights granted to the journal.

This is an open-access article distributed under the terms and conditions of the Creative Commons Attribution license (http://creativecommons.org/licenses/by/3.0/). 